\title{
RESEARCH PAPER \\ Transitioning to the safe and just space inside 'the doughnut' by means of agroecological niche food systems: insights from Chile and Uruguay
}

\section{Walter A.H. Rossing ${ }^{1}$, Annemarie Groot Kormelinck ${ }^{2}$, Florencia Alliaume ${ }^{3}$, Santiago Dogliotti ${ }^{3}$, Jessica Duncan ${ }^{4}$, Carlos Huenchuleo ${ }^{5}$, Laurens Klerkx ${ }^{6}$, Jacques Trienekens ${ }^{2}$, and Daniel Gaitán-Cremaschi ${ }^{1}$}

${ }^{1}$ Wageningen University and Research, Farming Systems Ecology Group. PO Box 430, 6700AK Wageningen, The Netherlands.

${ }^{2}$ Wageningen University and Research, Business Management \& Organisation. PO Box 8130, 6700EW Wageningen, The Netherlands.

${ }^{3}$ Universidad de la República. Av. Garzón 780, 11200 Montevideo, Uruguay.

${ }^{4}$ Wageningen University and Research, Rural Sociology Group. PO Box 8130, 6700EW Wageningen, the Netherlands.

${ }^{5}$ Pontificia Universidad Católica de Valparaíso, Escuela de Agronomía. Casilla 4-D, Quillota, Chile ${ }^{6}$ Wageningen University, Knowledge, Technology and Innovation Group. PO Box 8130, 6700EW Wageningen, The Netherlands.

\begin{abstract}
W.A.H. Rossing, A. Groot Kormelinck, F. Alliaume, S. Dogliotti, J. Duncan, C. Huenchuleo, L. Klerkx, J. Trienekens, and D. Gaitán-Cremaschi. 2020. Transitioning to the safe and just space inside 'the doughnut' by means of agroecological niche food systems: insights from Chile and Uruguay. Int. J. Agric. Nat. Resour. 295-311. To operate within the safe and just operating space captured by the doughnut metaphor, sustainability transitions are needed in the food system. Niche food systems with highly distinct practices and organization constitute a treasure chest of alternatives from which society can build new futures. Policy has little awareness of niche food systems and their potential contributions to sustainability transitions. Importantly, this limits society's ability to adapt. Here, we review findings from an ongoing scientific project into different components of the vegetable food systems in Chile and Uruguay. The aim of the project is to investigate options for transitioning to low- or nopesticide vegetable food systems. The results show: 1 . the presence of promising alternative vegetable food systems in Chile, which are, however, highly marginalized and disempowered; 2. a diversity of vertical and horizontal producer arrangements in Uruguay and the need for value-driven as well as market-driven engagement; and 3. major possibilities for improving production systems to arrive within the doughnut by taking a systems perspective at the farm scale that includes the farm families and their networks. Consequences of these findings for alternative vegetable food systems are discussed.
\end{abstract}

Keywords: Production system, support structures, value chain system, vegetable food system.

Received May 07, 2020. Accepted Oct 07, 2020.

Corresponding author: walter.rossing@wur.nl 


\section{Introduction}

In her seminal book Doughnut Economics, Kate Raworth (2017) described sustainable development as the challenge of ensuring that no one falls short on life's essentials while at the same time ensuring that we do not overshoot the boundaries that define the planetary environmental carrying capacity. The operating space between the socially-just lower threshold and the environmentally safe upper threshold delineates the room for economic development. By arranging the indicators for social and environmental performance on two concentric circles, the doughnut that is mentioned in the book title appears. The author makes a strong plea for attention to ways of organizing society that differ from the current mainstream in which the economic dimension is prioritized over the other dimensions. Such divergent organizational forms have been referred to as niches (e.g., Geels, 2002). These niches may coexist alongside mainstream societal structures but may also become part of the mainstream (e.g., organic agricultural value chains in some parts of the world) or even replace the mainstream (e.g., motor vessels replacing sailing ships as bulk carriers). Using diverse analytical tools, science has a role to play in highlighting these niches and their characteristics so that policymakers and society at large become aware of the diversity of options from which to select. Transdisciplinary science can support in various ways the sustainability transitions that would be needed to make promising niches mainstream (Fazey et al., 2018).

Production, transport, processing, selling and consumption of food are increasingly considered as connected subsystems, together constituting food systems (Ingram, 2011). Food systems may be defined at different geographical levels; e.g., from municipal to global, and with a focus on different components of diets. Here, we will consider vegetable food systems at the geographical scale of countries. The reason for considering food systems rather than their components, as would be more consistent with current organization of policy domains (e.g., with ministries on economic affairs and trade, social affairs, agriculture, environment) and scientific disciplines (e.g., agronomy, value-chain economics, sociology), is that pressing global environmental and social problems are typically caused by feedbacks among multiple components and therefore need to be addressed in concert (Magrini et al., 2016). The unsustainability of current dominant food systems has been addressed by a range of authors (e.g., Duru et al., 2015; Tittonell et al., 2016), calling for identification of alternatives that provide opportunities for sustainability transitions (Luederitz et al., 2017).

Ecological intensification (EI) has been proposed as a key component of sustainability transitions in food systems (Doré et al., 2011; Tittonell et al., 2016). The concept emphasizes the use of natural functionalities of ecosystems to support the provision of a variety of ecosystem services by agricultural production systems. Such ecologically intensive, rather than external input-intensive, systems have been given different names, appearing as organic, nature-inclusive, eco-agricultural, permaculture, or agro-ecological systems. Wezel et al. (2015) described the confusion surrounding the term agroecology and identify connotations as a scientific field, a social movement and a set of practices. As a set of practices, it has been linked strongly to utilization of the indigenous knowledge of traditional farmers for promoting biodiversity, sustaining yield without agrochemicals and conserving ecological integrity (Kremen \& Miles, 2012). The notion has also been used to lobby for, design and implement policies geared to supporting small farmers and community development (Nicholls \& Altieri, 2018). Finally, it represents a transdisciplinary scientific field in which concepts from systems ecology are linked to agriculture focusing particularly on smallholder farms, using a food system perspective (Gliessman, Putnam, \& Cohen, 2017).

Global annual supply of vegetables and fruits, including food waste, falls $34 \%$ short of population needs according to nutrition recommendations 
(Siegel, Ali, Srinivasiah, Nugent, \& Narayan, 2014). Country-specific supply-to-need ratios vary widely and are only slightly higher for high-income countries. Underconsumption of vegetables is more prevalent among consumers with lower incomes than for more affluent consumers, due both to dietary habits and lack of access. Current methods of vegetable production are based on high levels of external inputs (irrigation water, pesticides, fertilizers and energy), which put pressure on the environment. Pesticide use has been shown to negatively affect user and consumer safety and leads to consumer averseness to increase vegetable consumption (e.g., Van Hoi et al., 2013).

Problems of food security, expressed as availability, access and utilization of food, and of vegetables in particular, do not disappear when countries emerge from poverty and transition to greater levels of average affluence (Micha et al., 2015). Compared to developing countries, these transitional countries have received little attention regarding food system functioning, hindering the development of evidence-based food policy to balance economic growth, environmental impacts and social equity. Moreover, this lack of knowledge impedes global preparedness for similar problems in near-future transitioning countries now classified as developing.

Chile and Uruguay are transitional economies with distinctive economic development trajectories. Chile followed neo-liberal development policies, whereas Uruguay combined export-oriented policies with high levels of social spending and attention to smallholder family agriculture, encompassing most horticultural producers. Other drivers of the food systems include high (Chile, Gini index 44.4) and moderately high (Uruguay, Gini index 39.7) income inequality (https://data. worldbank.org/indicator/SI.POV.GINI/, accessed September 2020) and very high degrees of urbanization (88 and 95\% for Chile and Uruguay, respectively) (https://data.worldbank.org/indicator/SP.URB.TOTL.IN.ZS, accessed September 2020). Rapid changes in lifestyle, including the associated underconsumption of vegetables, led to rising obesity and obesity-related diseases in both countries over the past decade.

Vegetables in Chile and Uruguay originate mainly from domestic family agriculture. Current intensification models of vegetable production in both countries emphasize growth via external inputs of fertilizers, pesticides, water and energy, resulting in high exposure of producers and consumers to pesticides and economically unsustainable smallholder livelihoods (Dogliotti et al., 2014). For instance, in Uruguay the gross production value of the horticultural sector has declined by $12 \%$ since 2005 , and the number of growers decreased by $50 \%$ between 2004 and 2014. In Chile, over $75 \%$ of producers are marginalized smallholders, of which only $13 \%$ receive technical assistance. Analyses of vegetables sold in Chile and Uruguay have revealed pesticide residues in the majority of samples (e.g., Aldabe \& Dogliotti, 2014; Elgueta et al., 2017). Policy documents from both countries identify the need for low- or no-pesticide production methods, better articulation of on-farm production and value chains, and more equitable distribution of benefits (Aldabe \& Dogliotti, 2014; Schwartz, Kern, \& Hernández, 2013).

Scientific study of, and intervention in, food systems is both urgently needed and methodologically challenging due to the complexity of the systems, which transcends traditional scientific disciplines and policy domains (GaitánCremaschi et al., 2019). The aim of this paper is thus to introduce and apply a methodology for food system study and intervention. Concepts and results originate from HortEco, an ongoing scientific enquiry into vegetable food systems in Chile and Uruguay. The project set out to contribute to improved sustainability of vegetable food systems in Chile and Uruguay by studying, supporting and knowledge-sharing on methods for organizing production and marketing of high-value, low- or no-pesticide vegetables. We conceptualized food systems as consisting of three interacting components: the agricultural production system, the value chain and innovation 
support structures (Fig. 1A; Gaitán-Cremaschi interacting components, is influenced by external socioeconomic and environmental drivers that operate at larger spatial and temporal scales. Food system outcomes include environmental security, food nutrition and security, and social welfare. In a given geographic area multiple food systems may occur simultaneously due to the diversity of production systems, value chains and innovation support structures, as well as the linkages among them. Some of these may be components of the dominant way in which food is produced and consumed, others may constitute smaller-scale or more incipient instances.

A

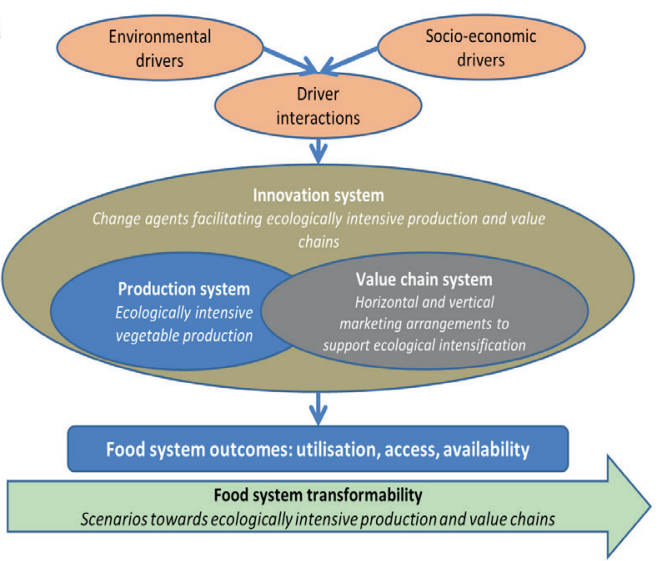

C

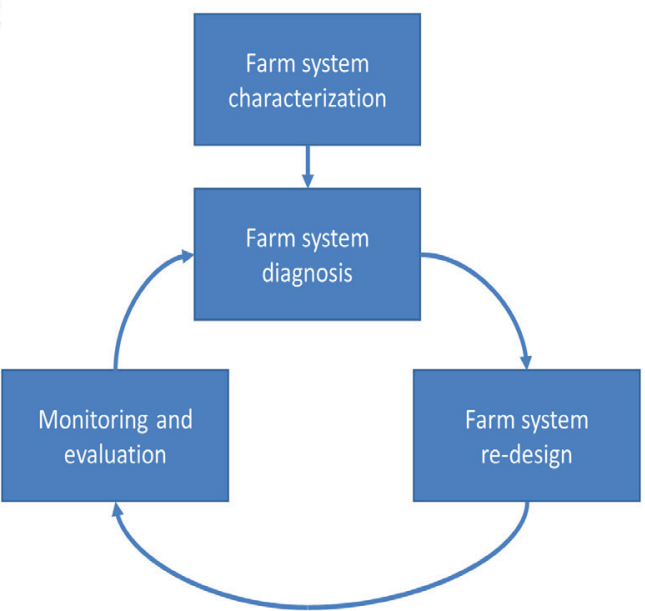
et al., 2019; 2020). The food system, through its

Within the HortEco project the food system concept has been used to structure interdisciplinary and transdisciplinary research into vegetable food systems in Chile and Uruguay as a whole and into their three constituent components. Not all aspects were studied in each country due to resource constraints (Table 1). Throughout the project the research team engaged with food system actors in niches with potential for sustainability transitions, responding to emerging needs and sharing emerging and existing research insights. Research questions addressed in this paper include: what is the diversity of vegetable food systems in Chile, and which niche food systems offer potential for sustainability transitions; which types of producer
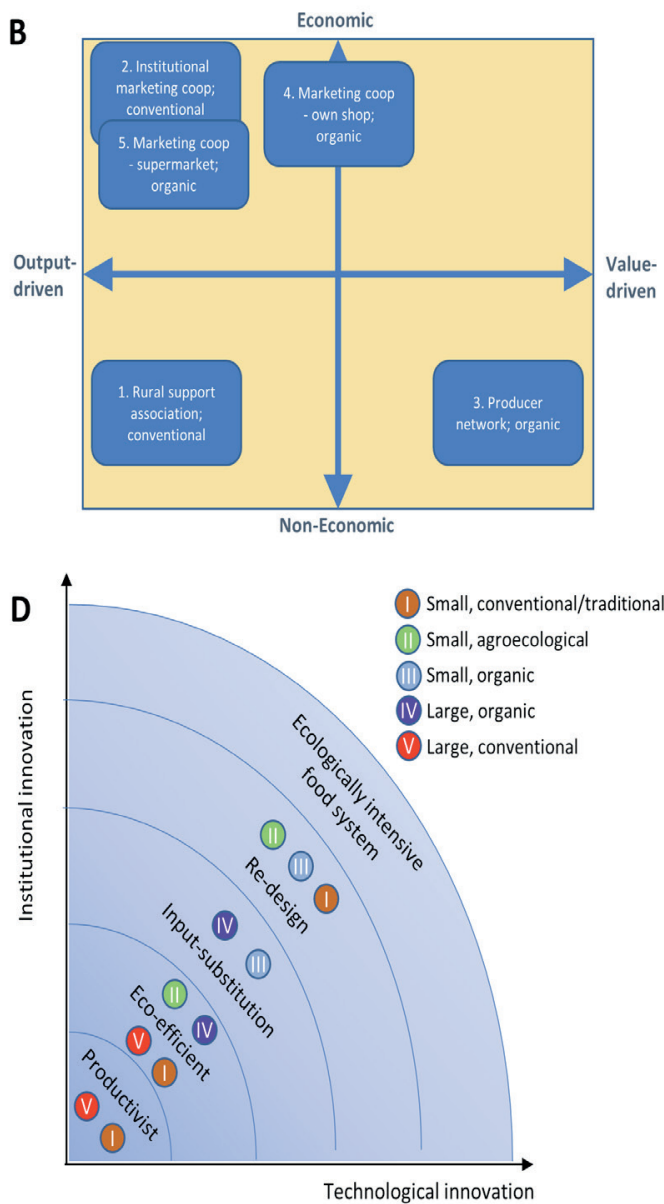

Figure 1. Main elements of the food system approach presented in this paper. A: Conceptual model of a food system, its outcomes and dynamics (Gaitán-Cremaschi et al., 2019); B: Mapping of producer organizations in value chains in Uruguay (Groot Kormelinck et al., 2019); C: Procedure used to analyze and redesign farms in Uruguay (after: Dogliotti et al., 2014); D. Mapping of Chilean vegetable food system types on the efficiency-substitution-redesign scale (after: GaitánCremaschi et al., 2020). For explanation see text. 
Table 1. Food system aspects addressed in the HortEco project, the countries in which they were studied, summaries of the methodologies used, and key references. The Innovation support system is mentioned for the sake of completeness, but no results are provided in this paper.

\begin{tabular}{|c|c|c|c|}
\hline Food system aspect & $\begin{array}{l}\text { Case study } \\
\text { country }\end{array}$ & Methodological elements & References \\
\hline $\begin{array}{l}\text { Vegetable food system } \\
\text { diversity }\end{array}$ & Chile & $\begin{array}{l}\text { Multilevel perspective (MLP); food system } \\
\text { diversity mapping based on interviews with } 33 \\
\text { sectoral actors; validation of the typology based } \\
\text { on } 20 \text { interviews; performance assessment of } \\
\text { food system types based on } 31 \text { questionnaires; } \\
\text { labeling as dominant, niche or hybrid systems } \\
\text { based on market share }\end{array}$ & $\begin{array}{l}\text { Gaitán-Cremaschi et al., 2019; } \\
\text { Gaitán-Cremaschi et al., } 2020\end{array}$ \\
\hline $\begin{array}{l}\text { Value chain systems } \\
\text { supporting ecological } \\
\text { intensification }\end{array}$ & Uruguay & $\begin{array}{l}\text { Qualitative case study design; interviews with } \\
\text { value chain and institutional actors - triangulated } \\
\text { with data from secondary sources }\end{array}$ & Groot Kormelinck et al., 2019 \\
\hline $\begin{array}{l}\text { Ecologically intensive } \\
\text { production systems }\end{array}$ & Uruguay & $\begin{array}{l}\text { Farming systems modeling; co-innovation; } \\
\text { strategic experimentation with novel } \\
\text { agroecological practices; model-based } \\
\text { exploration of the scope for whole-farm } \\
\text { performance improvement }\end{array}$ & $\begin{array}{l}\text { Dogliotti et al., 2005; Rossing et } \\
\text { al., 2010; Dogliotti et al., 2014; } \\
\text { Alliaume et al., 2017; Rossing } \\
\text { et al., } 2021\end{array}$ \\
\hline $\begin{array}{l}\text { Innovation support systems } \\
\text { for ecological intensification }\end{array}$ & Chile & $\begin{array}{l}\text { Food system diversity methodologies were also } \\
\text { used here }\end{array}$ & $\begin{array}{l}\text { Gaitán-Cremaschi et al., 2019; } \\
\text { Gaitán-Cremaschi et al., } 2020\end{array}$ \\
\hline
\end{tabular}

organizations exist in the fresh vegetable sector in Uruguay, and what are their potential contributions to sustainability transitions; and what options exist to ecologically intensify family-based vegetable farm systems in south Uruguay.

In the next sections the approaches used to analyze the vegetable food system and its components, the vegetable production system and the value chain system, (Table 1) are described succinctly. The innovation support systems are addressed in a separate paper. Next, the results are presented and options are discussed for unlocking the potential of agro-ecological niche food systems as incubators for transitioning 'back into the doughnut'.

\section{Materials and methods}

\section{Diversity of vegetable food systems in Chile}

Conceptual basis - Gaitán-Cremaschi et al. (2019) considered the diversity of food systems and their dynamics using the framework of the multilevel perspective (MLP) (Geels, 2002). In this framework, transition occurs through complex interactions between three levels of institutionalization.
The meso-level represents the dominant way of operating or the sociotechnical regime. This sociotechnical regime is composed of coherent and interconnected sets of social and technological elements, representing domains such as markets, culture, science, policy and technology. Its dominant position guarantees the stability needed for predictable day-to-day dynamics in society. Changes are targeted towards optimizing regime functioning. The regime resists radical changes that aim to replace it with a new regime. Such radical changes are typically generated in niches, where alternative markets, cultural or scientific elements, or technologies are developed by actors. The MLP concept postulates that changes in the regime are driven both by pressures derived from macrotrends at the institutional 'landscape' level and niche developments that open doors for opportunity in the regime. Multiple food systems may coexist at both regime and niche levels.

Methodology - A methodological framework consisting of 7 steps was developed to identify the diversity of food systems and applied to vegetable food systems in Chile. After setting the system boundaries to the vegetable sector and the Chilean national scale, face-to-face 
semi-structured interviews were held with 33 food system actors and experts to gain information on vegetable food systems from regional and national perspectives. The results of the interviews were coded and analyzed in terms of the variables distinguished for each of the food system components. For production systems, size, types of labor, types of ecologically intensive practices, level of tax compliance, level of management and production orientation were determined, following insights on farm typologies (Alvarez et al., 2018). Variables for value chains included network structure, value chain governance, network governance and level of informal relations in the value chain (Trienekens, van Velzen, Lees, Saunders, \& Pascucci, 2018). Mapping of the innovation support systems focused on those structures that affected use of pesticides and supported production and marketing of low- or no-pesticide vegetables. Combining the various alternative instances for each of the three elements into consistent combinations resulted in different food system types, the recognizability of which was checked based on feedback by 20 interviews with food system actors. For each of the food system types, 31 experts classified outputs in terms of economic performance, environmental protection, social welfare and food and nutrition security. Finally, the food system types were labeled as dominant, niche or hybrid based on current market share.

Value chain systems supporting ecologically intensive production in Uruguay

Conceptual basis - In emerging economies, vegetable producers are to a large extent dependent on markets for their livelihoods, and the manner in which value chains are organized determines the distribution of the value added between producer and consumer (Trienekens et al., 2018). While producer organizations have the potential to enhance the economic and social position of farmers and provide social and political benefits for the rural communities to which they belong, much less is known about the relationship between the performance of producer organizations and their organizational structures. This is of particular relevance as niche food systems are characterized by a lack of consolidated strategies, and insights into which approaches are effective can support their evolution. Groot Kormelinck et al. (2019) studies the producer organizations involved in conventional and organic vegetable value chain systems in Uruguay.

Methodology - Using an exploratory approach based on interviews and secondary information sources, a typology of vegetable producer organizations in Uruguay was constructed, and for each type, organizational characteristics were identified. The typology was based on a first round of interviews with key informants and resulted in 5 types of producer organizations, 2 in the conventional value chain system and 3 in the organic value chain system. The second round comprised of 50 interviews with producer organization members, and actors from the conventional and organic value chains and institutions (e.g., government, consumer organization, university, research institute). The interviews were analyzed using a set of 12 organization characteristics derived from the literature, of which 8 were finally selected to arrive at a cross-case analysis of the 5 different types of producer organizations.

\section{Ecological intensification of vegetable production systems in Uruguay}

Context - Vegetable farms in south Uruguay range from 4 to 50 ha in area, producing between 1 and 6 ha of vegetables (Dogliotti et al., 2014). Most of the labor is provided by the farm family. Farms are caught in an unsustainable spiral of continually decreasing produce prices, leading farmers to focus on the most profitable crops, which results in decreasing rotation lengths and soil degradation. This in turn is counteracted by increasing use of external inputs, while input prices continue to increase. The net result is that 
family farms are facing socially, economically and environmentally untenable conditions.

Methodology - Starting in the late 1990s, a combination of whole-farm modeling and on-farm co-innovation was used to explore options for ecologically intensive vegetable production systems (Dogliotti et al., 2014; Dogliotti et al., 2005). Modeling involved the use of FarmIMAGES, a mixed integer linear programming whole-farm model that enables quantitative analysis of trade-offs between economic and environmental objectives and the associated allocation of production activities. Production activities at the field level included crop rotations, intercrop activities such as growing green manure and application of animal manure, and beef cattle fattening activities. Management was described in terms of labor, machinery and capital inputs and desired (yield, gross margins, contributions to soil-C stocks) and nondesirable (pesticide use, soil erosion) outputs. The results showed that redesign of the entire farm system, rather than optimizing the management of individual crops, was essential for achieving substantial environmental-economic win-win outcomes.

The model-based findings were tested through coinnovation projects on 14 farms in which farmers, advisors and researchers collaborated on farm characterization, diagnosis and redesign (Fig. 1B), supported by social learning oriented monitoring and evaluation (Rossing et al., 2010; Rossing et al., 2021). After 5 years of co-innovation, yields of the main crops per farm increased by $40 \%$, average per capita income increased by $24 \%$ compared to municipal averages, income per hour increased by $50 \%$, and $17 \%$ more output per unit monetary input was achieved. The active organic matter fraction in the soils was increased by $26 \%$, while soil erosion as calculated by the RUSLE model was reduced by approximately 50\% (Dogliotti et al., 2014). Important ecologically intensive measures included increasing the rotation length by including additional crop species, lengthening pasture phases of beef cattle fattening, and including green manure and animal manure.
For three participating farms, the data collected during the co-innovation project were used to calculate family income and average soil erosion at the start ('Initial') and at the end ('Actual') of the co-innovation project. The three farms were selected to represent a range of land, mechanization and labor endowments, as researchers hypothesized that smaller farms would have difficulty keeping erosion below the 5 ton $\mathrm{ha}^{-1} \mathrm{yr}^{-1}$ threshold while generating sufficient economic returns. FarmDESIGN was used to explore the scope for further improvement of family income and average soil erosion ('Achievable') by adjusting areas of the crops already grown on the farm and by allowing uptake of new crops that have already been grown in the region.

\section{Results $^{1}$}

Diversity of vegetable food systems in Chile

The analysis identified 5 types of coexisting vegetable food systems that were recognizable to the 20 local experts. The types differed in their characteristics and the interconnections of their components. We present the 5 types by describing their production systems, value chain and innovation support structures, respectively, and characterize them as niche, dominant or hybrid system.

Food system type I, denoted as 'small, conventional/ traditional system' comprised farms smaller than 12 ha, with a conventional approach to farming that employs artificial fertilizers and pesticides and monocropping. Agroecological practices such as crop rotations, intercropping and local production of manure and compost occurred, especially in regions with strong indigenous farmer communities. Farmers engaged in this production type often had very limited economic resources,

${ }^{1}$ The results are drawn from the publications mentioned in Table 1 
which restricted quantities of externally purchased inputs. Nevertheless, very high levels of pesticide use were also reported by the experts. Pesticide use was regulated by the government agency $\mathrm{SAG}^{2}$, but mainly in terms of proper application of protocols rather than in terms of amounts used and residues on the produce.

Value chains in food system type I consisted of farmers selling to intermediaries who sold either to wholesalers or to retailers who served a variety of customers. This is the traditional way of marketing based on spot market (price, volume, quality) relations, with intermediaries in the wholesale markets holding the most favorable bargaining positions due to their overview and opportunities for product stocking. There was generally very little vertical (across links of the chain) or horizontal (between actors in the same link) cooperation, and lack of trust was common. Consumers were from low and medium income categories, purchasing products based on price and aesthetic quality.

Support structures in food system type I included formal education and public research centers. A specific platform of the Ministry of Agriculture, through INDAP ${ }^{3}$, delivered credit and advisory services. Public support regarding pesticides mainly concerned knowledge transfer on handling, application and disposal of residues. Private pesticide companies were mentioned as sources of information.

Food system type II, the 'small, agroecological system', comprised farms that applied agroecological management, which included practices such as saving seeds, application of bio-inputs (vermicompost, compost tea), and mulching. While pesticides and artificial fertilizers were used on some farms, overall levels of use were lower than in type I food systems.

\footnotetext{
${ }^{2}$ Servicio Agrícola y Ganadero - Crop and Livestock Service. within the Ministry of Agriculture

${ }^{3}$ Instituto de Desarrollo Agropecuario - Agricultural Development Institute, within the Ministry of Agriculture
}

Farms were mainly located in Chile's southern regions with strong influences from traditional (e.g., Mapuche) agricultural traditions.

Value chains in food system type II applied the traditional marketing system based on spot market arrangements. The agroecological aspects of products could not be marketed as, by law, this would require certification. Value chains in type II also included farm gate sales, home delivery and specialized shops, farmers' markets, agroecological markets and fairs. In these short marketing channels, often served by agroecological groups of producers and supported by consumer groups, arrangements were made for collective preparation of inputs for production, organization of market outlets, exchanges on product demand and joint pricesetting. Control systems were usually informal and relied on trust. Consumers were from all income categories and preferred local products.

Support structures in food system type II were dominated by NGOs operating in various regions, as well as regional, national and Latin American grassroots agroecology networks. This setting stimulated knowledge creation based on learning by doing and capacity building of actors. To a small extent public knowledge and financial support were found to be targeted or appropriate for farms and value chains in this food system type, reflecting the limited policy support. Recently, a federation of grassroots movements was founded to leverage greater political support.

Food system type III, 'small, organic system', included farms with strong tax formality that were similar in size to types I and II. The organic nature signifies that farms of this type complied with the Chilean Law No. 20089 of 2006 for organic production, regulated and legally enforced by SAG. Due to limited financial leeway farms in food system type III relied on organic certification through the Participatory Guarantee System (PGS), for which farmers organized themselves in 
associations of ecological producers. Production practices in type III farms were agro-ecological and included the use of organic inputs, insofar as they were allowed by law.

Value chains in food system type III benefited from formal certification as organic (legally synonymous with agroecological and ecological) and sold solely through short marketing channels that could be shared with type II producers. Arrangements included PGS shops and eco-fairs, which were organizationally demanding structures of collaboration among producers, associated with stricter arrangements concerning prices, volumes, entry fees and production planning. Quality control was imposed by internal audits and social control in the producer associations, legally required for organic certification and controlled by SAG. Consumers were largely urban and of medium and higher income classes, interested in food safety and sustainability of production.

Support structures in food system type III were similar to those in food system type II. The organic label, however, leveraged greater technical support by public institutions such as INIA (e.g., transfer groups on organic agriculture) and INDAP (through the organic branch of the SAT organization) and financial support through $\mathrm{CORFO}^{4}$ (e.g., funds to co-finance organic certification).

Food system type IV, 'large organic', included farms that exceeded farms from food system type III in size and in the reliance on external organic certification bodies rather than PGS systems. Production practices were based on organic external inputs to substitute for artificial pesticides and fertilizers that were not allowed under organic regulations.

\footnotetext{
${ }^{4}$ Corporación de Fomento de la Producción - Corporation for Production Development, within the Ministry of Economic Affairs
}

Value chains in this food system type were dominated by sales from producers to supermarkets. In these chains, supermarkets set volume and quality standards and implemented quality compliance audits. A range of fees was applied, such as shelf placement charges, fees for promotion, and fees for non-sale of product. Bargaining positions of producers were more favorable than those of conventional growers, since demand exceeded supply. A minor share of products went to specialized shops or restaurants, typically at spot prices. Consumers were largely urban and of medium and higher income classes, motivated by healthy eating.

Support structures in food system type IV were mainly through private technical assistance. Public institutions were found to provide much more limited support than in food system type V.

Production practices of farms in food system type $V$, 'large, conventional' food systems, involved purchased artificial pesticides and fertilizer, monocultures and intensive tillage. Pesticide use was found to vary widely, monitored more closely by SAG than for the smaller farms in food system types I to III.

Value chains in this food system type were traditional, similar to the ones found for food system types I and II. The bargaining power of producers was more favorable than for the smaller conventional farms, due to the size advantages of larger farms. Producers supplied wholesale markets, large intermediaries that in turn supplied agro-industry, public procurement programs or supermarkets. In the latter case arrangements were similar to those for large organic farms supplying supermarkets, extended by more stringent auditing of use of authorized pesticides only and compliance with preharvest intervals.

Support structures in food system type V were found in formal education centers and public research centers. Various programs of the Ministry enabled financial and technical support, driven by 
the needs of the farmers. Like the large organic farms in food system type IV, farmers in type $\mathrm{V}$ paid for (international) technical expertise when needed. Along with the purchase of inputs such as pesticides, advice was provided by marketing companies, similar to the case with food system type I.

The 5 food system types differed substantially in market share in terms of volume. The small/ traditional type I system and the large, conventional type $\mathrm{V}$ system together held a market share of close to $100 \%$ of the volume of vegetables in Chile, $80 \%$ of which were sold through highly consolidated wholesale markets. The remainder was sold through supermarkets, leaving only marginal amounts sold for food system types II to IV. In terms of the indicator market share, types $\mathrm{I}$ and $\mathrm{V}$ constituted the dominant food regime. Types II and III were radically different in terms of production systems, value chains and support structures. Food system type IV shared many elements with the dominant system $\mathrm{V}$, while having its own organic niche. Gaitán-Cremaschi et al. (2020) therefore consider type IV to be a hybrid system.

Value chain systems supporting ecologically intensive production in Uruguay

Value chains in the conventional vegetable sector are characterized by intermediaries between farmers and wholesalers and between wholesalers and final retail outlets, such as street markets, supermarkets, small retail stores and processing industries. Since supply exceeds demand, producers have little bargaining power and operate in a context of high price volatility and uncertainty. Producer organizations in the conventional vegetable sector belong to types 1 and 2 (Table 2; Fig. 1C). Producer organization type 1 comprises the approximately 100 Rural Support Associations, each with membership of 30-100 farmers. They are united in a union, which, similar to the associations, is a legal entity established under a law from 1915 with the purpose of channeling government support to producers. In addition to supporting farmers, the union and the associations develop social activities for the members and lobby with the government for support policies. Producer organization type 2 emerged from type 1 in response to a 2014 public procurement law that aimed to support family farmers (conventional and organic) by collective marketing of vegetables to institutional buyers (prisons, schools, army). To deliver the agreed amounts and quality on time, members need to make investments to enable logistics and storage facilities, while the government provides support for technical advice and compliance monitoring. As a result, horizontal collaboration and formalization is higher than in the case of the Rural Support Associations.

The organic sector is emerging, currently including approximately 120 certified producers. Whereas producer organizations in the conventional value chain are mainly established in response to public support, producer organizations in the organic (synonymous: agroecological) value chain are established in response to market demand. These value chains are shorter than in the conventional sector, with farmers that sell through an informal producer organization providing vegetables directly to consumers as box schemes or through street markets (type 3, Table 2) or as formal producer organizations to their own shops (type 4) or to supermarket chains (type 5). The producer organizations in these chains differ particularly in the degree to which the values associated with organic production and lifestyle are reflected in practice and in the degree of size, formalization and financial investment by members. Type 3 has a strong emphasis on values, interaction with consumers and accepting the trade-off with economic efficiency. From type 3 to type 5, the focus on efficiency in operations increases, which leads to higher levels of horizontal and vertical coordination 
Table 2. Types of producer organizations (POs) in the vegetable chain in Uruguay (after Groot Kormelinck et al., 2019).

\begin{tabular}{|c|c|c|c|c|c|}
\hline $\begin{array}{l}\text { Organizational } \\
\text { characteristics }\end{array}$ & $\begin{array}{l}\text { 1. Rural Support } \\
\text { Association }\end{array}$ & $\begin{array}{l}\text { 2. Institutional } \\
\text { marketing } \\
\text { cooperative }\end{array}$ & 3. Producer network & $\begin{array}{l}\text { 4. Marketing } \\
\text { cooperative with } \\
\text { own shop }\end{array}$ & $\begin{array}{l}\text { 5. Marketing } \\
\text { cooperative with } \\
\text { supermarket contract }\end{array}$ \\
\hline $\begin{array}{l}\text { Incentive for } \\
\text { establishment }\end{array}$ & Public & Public & Market & Market & Market \\
\hline Size (\# members) & $30-100$ & $10-20$ & $60-80$ & $5-12$ & $8-9$ \\
\hline $\begin{array}{l}\text { Production } \\
\text { orientation }\end{array}$ & Conventional & Conventional & Organic & Organic & Organic \\
\hline Product & Multiple & Vegetables & Multiple & Vegetables & Vegetables \\
\hline $\begin{array}{l}\text { Member } \\
\text { investment }\end{array}$ & No & Yes & No & Yes & Yes \\
\hline Formalization & Low & High & Low & High & High \\
\hline Activity & Social, political & Economic & $\begin{array}{l}\text { Social, political, } \\
\text { economic }\end{array}$ & Economic & Economic \\
\hline Objective & - & - & Value-driven & $\begin{array}{l}\text { Value-driven \& } \\
\text { output-driven }\end{array}$ & Output-driven \\
\hline Coordination & Low & Medium & Low & Medium & High \\
\hline Horizontal & $\begin{array}{l}\text { Social activities, } \\
\text { lobby for } \\
\text { and channel } \\
\text { government support }\end{array}$ & $\begin{array}{l}\text { Production } \\
\text { planning, transport, } \\
\text { payments, } \\
\text { collective } \\
\text { infrastructure }\end{array}$ & $\begin{array}{l}\text { Exchange (social, } \\
\text { production, market } \\
\text { information) }\end{array}$ & $\begin{array}{l}\text { Production } \\
\text { planning, quality } \\
\text { setting, logistics, } \\
\text { pricing }\end{array}$ & $\begin{array}{l}\text { Production planning, } \\
\text { quality setting and } \\
\text { control, logistics, } \\
\text { pricing, side- } \\
\text { activities }\end{array}$ \\
\hline Vertical & - & $\begin{array}{l}\text { 3-party contracts } \\
\text { specifying volume, } \\
\text { quality, delivery } \\
\text { conditions }\end{array}$ & $\begin{array}{l}\text { Partially collective } \\
\text { commercialization } \\
\text { directly to consumers } \\
\text { through box schemes } \\
\text { and street markets }\end{array}$ & $\begin{array}{l}\text { Integration with } \\
\text { own shop and } \\
\text { its manager: } \\
\text { Production, } \\
\text { logistics, quality }\end{array}$ & $\begin{array}{l}\text { Contract with } \\
\text { supermarket: } \\
\text { Product, quality, } \\
\text { packaging, branding, } \\
\text { logistics, investments }\end{array}$ \\
\hline
\end{tabular}

\section{Ecological intensification of vegetable production systems in Uruguay}

At the start of the co-innovation project the three farms all showed low levels of family income in an absolute sense and in comparison to income levels in neighboring rural communities, because two of the farms suffered from very high levels of soil erosion when the collaboration began (Fig. 2, 'Initial'). The two larger farms, the mixed (beef cattle and vegetables) farm 1 (11 ha with 1.5 ha planted in vegetables, no mechanization, 1 FTE labor) and farm 2 (20 ha with 7.6 ha planted in vegetables, no mechanization, 2 FTE labor), were able to improve family income by integrating pasture and cereal phases in the vegetable rotation to enhance chemical, physical and biological soil fertility, while substantially reducing soil erosion through improved spatial layout of the fields on the farms. The smallest farm 3 (4.4 ha of vegetables) was able to double family income over the course of the co-innovation project, but only at the expense of increasing soil erosion (Fig. 2, 'Actual').

The model-based explorations (Fig. 2, 'Achievable') showed that by changing areas of current vegetable crops and uptake of vegetables that were already grown in the region, family income could be further increased on all 3 farms. For farms 1 and 2 this was achieved while simultaneously reducing soil erosion to near the erosion threshold of 5 ton ha $^{-1} \mathrm{yr}^{-1}$, while for farm 3 this was only able to be achieved by increasing soil 


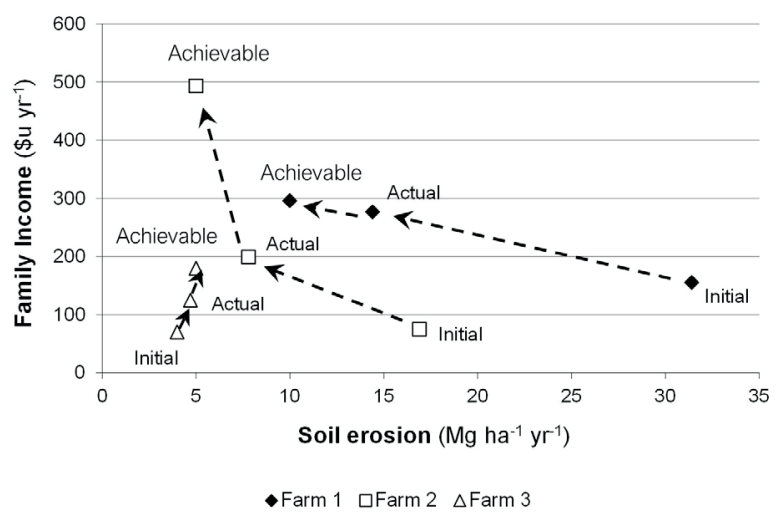

Figure 2. Family income and average farm soil erosion calculated for three family vegetable farms in south Uruguay at the start of a co-innovation project ('Initial'), at the end ('Actual'), and as predicted by a model-based exploration of options aimed to enhance family income, while reducing soil erosion or maintaining it under the maximum of 5 tons ha-1 $\mathrm{yr}^{-1}$ ('Achievable').

erosion. The size of farm 3 limited uptake of erosion-reducing pasture phases, as these would compromise economic viability. The results showed the difficulty of bringing soil erosion 'within the doughnut' for the prevailing labor and economic viability constraints on small vegetable farms.

\section{Discussion and conclusion}

We reviewed recent results from an ongoing scientific program addressing vegetable food system diversity in Chile and Uruguay to reveal less visible niche food systems and their components, which hold promise for reversing negative impacts of current industrial vegetable food systems. While a full comparative perspective of both countries was beyond the scope of the work, a number of insights can be gleaned from the results available to date.

The vegetable food system typology for Chile revealed the presence of a diversity of vegetable food systems alongside the dominant ones. According to the 53 experts involved in the study the alternative and hybrid food systems scored substantially better in terms of social welfare and environmental protection than did the dominant food systems. Hill and MacRae (1996) introduced the efficiency-substitution-redesign transition ladder to describe increasing levels of change towards sustainable food systems. Tittonell (2014) recontextualized the ladder to emphasize the importance of combining technological change with institutional change when climbing the ladder (Fig. 1D). Based on the food system typology, Gaitán-Cremaschi et al. (2020) considered the small agroecological (type II) and small organic (type III) types as promising niches due to the redesign elements encountered in their production systems and market arrangements. Diversified cropping systems, participatory certification and short value chains were all structural elements that affected food system functioning and formed a break from industrial systems. While ecologically intensive agroecological production practices were also encountered within dominant food system type I, they represented replication of traditional practices rather than attempts at sustainability transitioning. Nevertheless, such practices could well serve as inspiration for intentional system redesign. The large organic systems (type IV) were characterized as eco-efficient and inputsubstitution oriented, resembling what Darnhofer et al. (2009) called the conventionalization of organic agriculture. Despite their promise, the niche food system types II and III were considered highly marginalized and disempowered. 
Analysis of organic value chain systems showed that producer organizations responded to an increasing market demand for organic vegetables, but at the same time benefited from structural public support that enabled their performance. Similarly, market demand in Chile drove the emergence of small agroecological and organic niche food system types. At the same time, the publicly funded farmer union in Uruguay served as an important stepping-stone for the development of agroecological networks. Such network development lagged behind in Chile. Bijman (2016), in an extensive study on the marginal role played by cooperatives in the European Union's New Member States, found that the low level of self-organization and networking reflected a persistent societal characteristic with implications beyond poor functioning of cooperatives. Overcoming these societal barriers calls for trustworthy and skillful leadership to build trust and cope with free-rider issues. This may well be the task for the agroecological movement in Chile. In this respect Uruguay has a very distinct history, with origins of cooperative formation dating back to the 1870s (Groot Kormelinck et al., 2019). The extent to which geographic context plays a role, such as the close proximity among actors with potentially complementary competencies in Uruguay, deserves further attention to support network development in a large country such as Chile.

A further feature distinguishing value chains of the niche vegetable food systems studied in Uruguay is the orientation towards human values in addition to market values. Short market chains in combination with contacts among consumers and producers and limited structuration among producers are reflected in organizational characteristics. The most strongly value-driven producer organization was also acting in the policy realm, fulfilling an important advocacy role in Uruguayan deliberations on implementation of the National Agroecology Plan. In a study on internalization of agro-environmental policies by farmers, Stobbelaar et al. (2009) showed how internal motivation of organic farmers in combination with strong institutional connections led to more effective nature conservation than for predominantly financial reward oriented conventional farmers.

For the production system component, the example from Uruguay demonstrated how consistent transdisciplinary research over more than a decade, flexibly shifting between different levels of participation of farmers and scientists in the development of knowledge and skills for on-farm sustainability transitions, resulted both in substantial economic and environmental advances, as well as clear prospects for future opportunities to transition to "within the doughnut'. Reaping these opportunities requires often profound changes in farm layout and production methods across thousands of vegetable farms. Experience shows that such reconfiguration of production systems is possible starting from the experimental niches provided by co-innovation projects (Dogliotti et al., 2014; Albicette et al., 2017; Rossing et al., 2021). In addition to this intervention-oriented phase of transition research at the production system level, various scientific-experimental phases have been part of the transition project portfolio. One example is work on mulch-based reduced-tillage vegetable bed systems as a means to decrease erosion on small vegetable farms while not compromising social or economic objectives (Alliaume, Rossing, Tittonell, \& Dogliotti, 2017). Another example is on-station work on nitrogen and weed management in reduced tillage, supported by a farmer user group (Scarlato et al., 2020). These scientific findings are now available for next rounds of testing and improvement in on-farm co-innovation projects. Our research found no government-supported co-innovation projects in Chile, and while certain NGOs have assumed such a role, a more diverse and effective knowledge production landscape may emerge when training of researchers, extension agents and policy analysts includes transdisciplinary approaches as reference educational material. 
The results presented here paint a partial picture, as not all components of the vegetable food systems could be covered for each country, and the research approach relied largely on qualitative approaches for lack of quantitative information. The merit of the work is in showing what a food systems perspective can contribute and in introducing methods for systematically studying food systems and their components. Not only the analytical results but also the process of continued engagement between researchers and social actors during the research project, contributed to the production of actionable knowledge (Geertsema et al., 2016). This shows how science can play a role in supporting the development of agroecological niches and grassroots innovation movements (e.g., Smith et al., 2014) if it is able to overcome its own dominant manner of operation, which has resulted in a disconnect from society (Klerkx et al., 2017; Fazey et al., 2018).

We conclude that both in Chile and in Uruguay and alongside the dominant industrial vegetable food systems, niche vegetable food systems exist that hold promise for sustainability transitions to the safe and just inside 'the doughnut' by changing production systems, value chain systems and their support structures. The Uruguayan case showed how value-based broad networking in combination with market-driven smaller and targeted initiatives created a fabric that enabled institutional support as well as market persistence. Niche vegetable food systems in Chile showed elements of increased internal and external networking, but persistent conflicts between actors need to be overcome by enhanced communication and leadership to build trusting relationships.

\section{Acknowledgements}

The HortEco project was funded through the Global Challenge Programme of the Dutch Science Foundation NWO-WOTRO (contract nr. W 08.250.304) and co-funded by ANII (Agencia Nacional de Investigación e Innovación, Uruguay), CNFR (Comisión Nacional de Fomento Rural, Uruguay), CAMM (Comisión Administradora del Mercado Modelo, Uruguay) and the Faculty of Agronomy of the University of the Republic, Uruguay.

This manuscript summarises the authors' intended contribution at the Workshop on Challenges for Agroecology Development for the Building of Sustainable Agri-Food Systems (CRP), which was due to take place at the Faculty of Agricultural Sciences, University of Chile, Santiago de Chile, on 11-13 November 2019, and which was sponsored by the OECD Co-operative Research Programme: Biological Resource Management for Sustainable Agricultural Systems. Although due to the circumstances the workshop did not take place as a physical meeting and contributions intended to be supported by the OECD CRP are published in this Thematic Issue.

\section{Disclaimer}

The opinions expressed and arguments employed in this manuscript are the sole responsibility of the authors and do not necessarily reflect those of the OECD or of the governments of its Member countries.

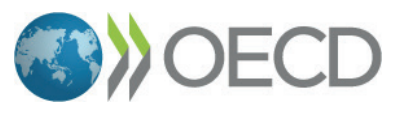

\section{Resumen}

W.A.H. Rossing, A. Groot Kormelinck, F. Alliaume, S. Dogliotti, J. Duncan, C. Huenchuleo, L. Klerkx, J. Trienekens, y D. Gaitán-Cremaschi. 2020. La transición al espacio seguro y justo dentro de "la rosquilla" mediante sistemas agroecológicos de alimentos de nicho: reflexiones de Chile y Uruguay. Int. J. Agric. Nat. Resour. 295-311. Para permanecer dentro del espacio operativo seguro y justo capturado por la metáfora de la rosquilla (“doughnut metaphor"), 
se necesitan transiciones hacia sistemas alimentarios sostenibles. Los sistemas alimentarios de nicho, compuestos por distintas prácticas y formas de organización, constituyen un tesoro de alternativas a partir de las cuales la sociedad puede construir nuevos futuros. La política tiene poca conciencia de los sistemas alimentarios de nicho y sus potenciales contribuciones a las transiciones de sostenibilidad. Es importante destacar que esto limita la capacidad de adaptación de la sociedad. Aquí, revisamos los hallazgos de un proyecto científico en curso sobre diferentes componentes de los sistemas alimentarios hortícolas en Chile y Uruguay. El objetivo del proyecto es investigar opciones para la transición hacia sistemas alimentarios hortícolas con bajo contenido de pesticidas o sin pesticidas. Los resultados muestran (1) en Chile, la existencia de sistemas alimentarios hortícolas alternativos con características prometedoras, que, sin embargo, se encuentran marginados y desempoderados; (2) en Uruguay, una diversidad de acuerdos verticales y horizontales de los productores y la necesidad de una participación impulsada por los valores y el mercado; y (3) grandes posibilidades de mejorar los sistemas de producción hortícolas para ubicarse dentro de la rosquilla, mediante la adopción de una perspectiva de sistema a escala de la granja que incluya a las familias de agricultores y sus redes. Se discuten las consecuencias de estos hallazgos para los sistemas alimentarios hortícolas alternativos.

Palabras clave: Estructuras de soporte, sistema alimentario hortícola, sistema de la cadena de valor, sistema de producción.

\section{References}

Albicette, M. M., Leoni, C., Ruggia, A., Scarlato, S., Blumetto, O., Albín, A., \& Aguerre, V. (2017). Co-innovation in family-farming livestock systems in rocha, Uruguay: A 3-year learning process. Outlook on Agriculture, 46(2), 92-98. https://doi.org/10.1177/0030727017707407

Aldabe, L., \& Dogliotti, S. (2014). Plan estratégico para el sector horticola Uruguayo. Informe Final para la Región Sur.

Alliaume, F., Rossing, W. A. H., Tittonell, P., \& Dogliotti, S. (2017). Modelling soil tillage and mulching effects on soil water dynamics in raised-bed vegetable rotations. European Journal of Agronomy, 82, 268-281. https://doi. org/10.1016/j.eja.2016.08.011

Alvarez, S., Timler, C. J., Michalscheck, M., Paas, W., Descheemaeker, K., Tittonell, P., ... Groot, J. C. J. (2018). Capturing farm diversity with hypothesis-based typologies: An innovative methodological framework for farming system typology development. PLoS ONE, 13(5), 1-24. https://doi.org/10.1371/journal.pone.0194757
Bijman, J. (2016). The changing nature of farmer collective action: introduction to the book. In Bijman, J., Muradian, R., Schuurman, J. (Eds.), Cooperatives, Economic Democratization and Rural Development. (p. 320). Edward Elgar Publishers, Cheltenham.

Darnhofer, I., Lindenthal, T., Bartel-Kratochvil, R., \& Zollitsch, W. (2009). Conventionalisation of organic farming practices: From structural criteria towards an assessment based on organic principles. Sustainable Agriculture, 2 , 331-349. https://doi.org/10.1007/978-94-0070394-0_18

Dogliotti, S., García, M. C., Peluffo, S., Dieste, J. P., Pedemonte, A. J., Bacigalupe, G. F., ... Rossing, W. A. H. (2014). Co-innovation of family farm systems: A systems approach to sustainable agriculture. Agricultural Systems, 126, 7686. https://doi.org/10.1016/j.agsy.2013.02.009

Dogliotti, S., Rossing, W. A. H., \& Ittersum, M. K. Van. (2005). A method for exploring sustainable development options at farm scale: a case study for vegetable farms in South Uruguay. Agricultural Systems, 86, 29-51. https://doi. org/10.1016/j.agsy.2004.08.002 
Doré, T., Makowski, D., Malézieux, E., MunierJolain, N., Tchamitchian, M., \& Tittonell, P. (2011). Facing up to the paradigm of ecological intensification in agronomy: Revisiting methods, concepts and knowledge. European Journal of Agronomy, 34, 197-210. https://doi. org/10.1016/j.eja.2011.02.006

Duru, M., Therond, O., \& Fares, M. (2015). Designing agroecological transitions; A review. Agronomy for Sustainable Development, 35, 1237-1257. https://doi.org/10.1007/s13593-015-0318-x

Elgueta, S., Moyano, S., Sepúlveda, P., Quiroz, C., \& Correa, A. (2017). Pesticide residues in leafy vegetables and human health risk assessment in North Central agricultural areas of Chile. Food Additives \& Contaminants: Part $B, 10,105-112$.

Fazey, I., Schäpke, N., Caniglia, G., Patterson, J., Hultman, J., van Mierlo, B., ... Wyborn, C. (2018). Ten essentials for action-oriented and second order energy transitions, transformations and climate change research. Energy Research and Social Science, 40, 54-70. https://doi. org/10.1016/j.erss.2017.11.026

Gaitán-Cremaschi, D., Klerkx, L., Duncan, J., Trienekens, J. H., Huenchuleo, C., Dogliotti, S., ... Rossing, W. A. H. (2019). Characterizing diversity of food systems in view of sustainability transitions. A review. Agronomy for Sustainable Development, 39(1). https://doi.org/10.1007/ s13593-018-0550-2

Gaitán-Cremaschi, D., Klerkx, L., Duncan, J., Trienekens, J. H., Huenchuleo, C., Dogliotti, S., ... Rossing, W. A. H. (2020). Sustainability transition pathways through ecological intensification: an assessment of vegetable food systems in Chile. International Journal of Agricultural Sustainability, 18, 131-150. https://doi.org/10.1 080/14735903.2020.1722561

Geels, F. W. (2002). Technological transitions as evolutionary reconfiguration processes: A multi-level perspective and a case-study. Research Policy, 31(8-9), 1257-1274. https://doi.org/10.1016/ S0048-7333(02)00062-8

Geertsema, W., Rossing, W. A., Landis, D. A., Bianchi, F. J., Van Rijn, P. C., Schaminée, J. H.,
... Van Der Werf, W. (2016). Actionable knowledge for ecological intensification of agriculture. Frontiers in Ecology and the Environment, 14, 209-216. https://doi.org/10.1002/fee.1258

Gliessman, S., Putnam, H., \& Cohen, R. (2017). Agroecology and Basis, participatory knowledge production and exchange as a Agroecology, for food system change: The case of the community network. In A. Wezel (Ed.), Agroecological practices for sustainable agriculture principles, applications, and making the transition (pp. 201228). London: Imperial College Press.

Groot Kormelinck, A., Bijman, J., \& Trienekens, J. (2019). Characterizing Producer Organizations: The case of organic versus conventional vegetables in Uruguay. Journal of Rural Studies, 69, 65-75. https://doi.org/10.1016/j. jrurstud.2019.04.012

Hill, S. B., \& MacRae, R. J. (1996). Conceptual Framework for the Transition from Conventional to Sustainable Agriculture. Journal of Sustainable Agriculture, 7, 81-87. https://doi. org/10.1300/J064v07n01_07

Ingram, J. (2011). A food systems approach to researching food security and its interactions with global environmental change. Food Security, 3, 417-431. https://doi.org/10.1007/s12571-0110149-9

Kleijn, D., Bommarco, R., Fijen, T. P. M., Garibaldi, L. A., Potts, S. G., \& van der Putten, W. H. (2019). Ecological Intensification: Bridging the Gap between Science and Practice. Trends in Ecology and Evolution, 34, 154-166. https://doi. org/10.1016/j.tree.2018.11.002

Klerkx, L., Seuneke, P., de Wolf, P., \& Rossing, W. A. H. (2017). Replication and translation of coinnovation: The influence of institutional context in large international participatory research projects. Land Use Policy, 61, 276-292. https://doi. org/10.1016/j.landusepol.2016.11.027

Kremen, C., \& Miles, A. (2012). Ecosystem services in biologically diversified versus conventional farming systems: benefits, externalities, and trade-offs. Ecology and Society 17(4), 1-23.

Luederitz, C., Schäpke, N., Wiek, A., Lang, D. J., Bergmann, M., Bos, J. J., ... Westley, F. R. 
(2017). Learning through evaluation - A tentative evaluative scheme for sustainability transition experiments. Journal of Cleaner Production, 169, 61-76. https://doi.org/10.1016/j. jclepro.2016.09.005

Magrini, M. B., Anton, M., Cholez, C., Corre-Hellou, G., Duc, G., Jeuffroy, M. H., ... Walrand, S. (2016). Why are grain-legumes rarely present in cropping systems despite their environmental and nutritional benefits? Analyzing lock-in in the French agrifood system. Ecological Economics, 126, 152-162. https://doi.org/10.1016/j.ecolecon.2016.03.024

Micha, R., Khatibzadeh, S., Shi, P., Andrews, K. G., Engell, R. E., \& Mozaffarian, D. (2015). Global, regional and national consumption of major food groups in 1990 and 2010: A systematic analysis including 266 country-specific nutrition surveys worldwide. BMJ Open, 5(9). https://doi. org/10.1136/bmjopen-2015-008705

Nicholls, C. I., \& Altieri, M. A. (2018). Pathways for the amplification of agroecology. Agroecology and Sustainable Food Systems, 42, 1170-1193. https://doi.org/10.1080/21683565.2018.1499578

Raworth, K. (2017). Doughnut Economics. Seven ways to think like a 21st-century economist. Penguin Random House, UK.

Rossing, W. A. H., Albicette, M. M., Aguerre, V., Leoni, C., Ruggia, A., \& Dogliotti, S. (2021). Crafting actionable knowledge on ecological intensification: lessons from co-innovation approaches in Uruguay and Europe. Agricultural Systems, in prep.

Rossing, W. A. H., Dogliotti, S., Franca, G., Cittadini, E., Bacigalupe, G., Cittadini, E., ... Cittadini, E. (2010). Project design and management based on a co-innovation framework: Towards more effective research intervention for sustainable development of farming systems. 9th European IFSA Symposium, (July), 402-412. Retrieved from http://ifsa.boku.ac.at/cms/fileadmin/Proceeding2010/2010_WS1.4_Rossing.pdf

Scarlato, M., Rieppi, M., Bajsa, N., Illarze, G., Alliaume, F., Trasante, T., ... Dogliotti, S. (2020). Laboreo reducido en cultivo de cebolla orgánico: el manejo del nitrógeno y el control de malezas nos siguen desafiando. In Proc. VIII Congreso Sociedad Cientifica Latinoamericana de Agroecología
SOCLA,. Montevideo, Uruguay: Sociedad Científica Latinoamericana de Agroecología SOCLA.

Schwartz, M., Kern, W., \& Hernández, M. (2013). Diagnóstico y estrategia de desarrollo para el sector horticola Chilena.

Siegel, K. R., Ali, M. K., Srinivasiah, A., Nugent, R. A., \& Narayan, K. M. V. (2014). Do We Produce Enough Fruits and Vegetables to Meet Global Health Need? PLoS ONE, 9(8), e104059. https:// doi.org/10.1371/journal.pone.0104059

Smith, A., Fressoli, M., \& Thomas, H. (2014). Grassroots innovation movements: Challenges and contributions. Journal of Cleaner Production, 63, 114-124. https://doi.org/10.1016/j. jclepro.2012.12.025

Stobbelaar, D. J., Groot, J. C. J., Bishop, C., Hall, J., \& Pretty, J. (2009). Internalization of agrienvironmental policies and the role of institutions. Journal of Environmental Management, 90 Suppl 2, S175-84. https://doi.org/10.1016/j. jenvman.2008.11.019

Tittonell, P. (2014). Ecological intensification of agriculture - sustainable by nature. Current Opinion in Environmental Sustainability, 8, 53-61. https://doi.org/10.1016/j.cosust.2014.08.006

Tittonell, P., Klerkx, L., Baudron, F., Félix, G. F., Ruggia, A., Apeldoorn, D. Van, ... Rossing, W. A. H. (2016). In Lichtfouse, E. (Ed), Sustainable Agriculture Reviews, 12, 1-34. Springer International. https://doi.org/10.1007/978-94-007-5961-9

Trienekens, J., van Velzen, M., Lees, N., Saunders, C., \& Pascucci, S. (2018). Governance of market-oriented fresh food value chains: Export chains from New Zealand. International Food and Agribusiness Management Review, 21, 249268. https://doi.org/10.22434/IFAMR2017.0063

Van Hoi, P., Mol, A., \& Oosterveer, P. (2013). State governance of pesticide use and trade in Vietnam. NJAS - Wageningen Journal of Life Sciences, 67, 19-26. https://doi.org/10.1016/j.njas.2013.09.001

Wezel, A., Soboksa, G., McClelland, S., Delespesse, F., \& Boissau, A. (2015). The blurred boundaries of ecological, sustainable, and agroecological intensification: a review. Agronomy for Sustainable Development, 35, 1283-1295. https://doi. org/10.1007/s13593-015-0333-y 